\title{
CASE REPORT OF A PATIENT WITH cANCA VASCULITIS WITHOUT AIRWAY INVOLVEMENT
}

\author{
PRIKAZ BOLESNICE S c-ANCA VASKULITISOM \\ BEZ ZAHVAĆENOSTI DIŠNIH PUTOVA
}

\author{
Željka Kardum ${ }^{1}$ Jasminka Milas Ahić, ${ }^{1,2}$, Ivana Kovačević1, Ana Marija Lukinac', \\ Ana Kovač ${ }^{1}$, Kristina Kovačević Stranski ${ }^{1}$, Višnja Prus ${ }^{1,2}$
}

\begin{abstract}
${ }^{1}$ Division of Rheumatology, Clinical Immunology, and Allergology, Department of Internal Medicine, UHC Osijek, Osijek, Croatia / Zavod za reumatologiju, kliničku imunologiju i alergologiju, Odjel za internu medicinu, Klinički bolnički centar Osijek, Hrvatska ${ }^{2}$ Faculty of Medicine, Josip Juraj Strossmayer University of Osijek, Osijek, Croatia / Medicinski fakultet Sveučilišta Josipa Jurja Strossmayera u Osijeku, Osijek, Hrvatska
\end{abstract}

Corresponding author / Adresa autora za dopisivanje:

\section{Željka Kardum}

Division of Rheumatology, Clinical Immunology and Allergology

/ Zavod za reumatologiju, kliničku imunologiju i alergologiju

Department of Internal Medicine / Klinika za unutarnje bolesti

University Hospital Center Osijek / Klinički bolnički centar Osijek

J. Huttlera 4

31000 Osijek

Croatia / Hrvatska

Phone / Tel.: 00385-91-3911945

E-mail: zeljkakardum@gmail.com

\section{ABSTRACT}

Antineutrophil cytoplasmic autoantibody (ANCA)-associated vasculitis (AAV) is a small-vessel vasculitis, characterized by necrotizing inflammation of small vessels and positive ANCAs. cANCAs are directed against proteinase-3 (PR-3) and are specific for granulomatosis with polyangiitis (GPA, formerly known as Wegener's disease), although their role in the immunopathology of the disease is still unclear. This is why the European Medicines Agency suggested that cANCA positivity, in addition to the clinical picture, can be enough for the diagnosis of GPA. Granulomatosis with polyangiitis is characterized by granulomatous inflammation that usually involves the upper and lower respiratory tract, necrotizing vasculitis that affects small and medium-sized vessels, and often rapidly progressive glomerulonephritis. We present a patient with an unusual presentation of cANCA-associated vasculitis, who presented with arthritis, palpable purpura on legs, and pauci-immune necrotizing glomerulonephritis with highly positive cANCA antibodies, without any signs or symptoms of airway involvement. Although renal-limited ANCA vasculitis is recognized as a separate entity, our patient also had signs of skin and joint involvement and prominent constitutional symptoms that contributed to the diagnosis of systemic disease.

In this paper, we present a patient with an atypical course of GPA, which can also be called a limited form of the disease. An atypical course or limited form belongs to the group of sine syndromes in inflammatory rheumatic diseases, which are not very common, but should be considered in the differential diagnosis. To our knowledge, there are only a few described case reports with a similar presentation.

KEYWORDS: Anti-neutrophil cytoplasmic antibody-associated vasculitis - diagnosis, pathology; Antibodies, antineutrophil cytoplasmic - analysis; Granulomatosis with polyangiitis - diagnosis, drug therapy, pathology; Purpura etiology; Glomerulonephritis - etiology; Arthritis - etiology

\section{SAŽETAK}

Vaskulitis povezan s antineutrofilnim citoplazmatskim protutijelima (engl. Anti-neutrophil Cytoplasmatic Antibody - ANCA) ili skraćeno ANCA vaskulitis (engl. ANCA-associated vasculitis - AAV) jest vaskulitis malih krvnih žila karakteriziran nekrotizirajućom upalom malih krvnih žila i pozitivnim antineutrofilnim citoplazmatskim protutijeli- 
ma. Protutijela c-ANCA usmjerena su na proteinazu 3 (PR-3) i karakteristična za granulomatozu s poliangiitisom (GPA), prije poznatu kao Wegenerova bolest, premda njihova uloga u imunopatologiji bolesti još nije razjašnjena. Upravo zbog visoke specifičnosti protutijela Europska agencija za lijekove predložila je da pozitivna protutijela c-ANCA uz popratnu kliničku sliku budu dovoljna za dijagnozu GPA. Granulomatozu s poliangiitisom karakteriziraju granulomatozna upala koja uobičajeno zahvaća gornje i donje dišne putove, nekrotizirajući vaskulitis što zahvaća male i srednje velike krvne žile i često prisutan brzoprogresivni glomerulonefritis. U ovom radu prikazana je bolesnica s neuobičajenom prezentacijom c-ANCA vaskulitisa uz prisutne artritis, palpabilnu purpuru na nogama, pauciimuni nekrotizirajući glomerulonefritis i visokopozitivna protutijela c-ANCA, međutim, bez znakova i simptoma zahvaćanja dišnih putova. Premda je ANCA vaskulitis ograničen na bubreg otprije poznat kao poseban entitet, naša je bolesnica također imala prisutno zahvaćanje kože i zglobova te izražene konstitucijske simptome, što upućuje na sustavni oblik bolesti.

Prikazana je bolesnica s atipičnim oblikom GPA, koji se može nazvati i ograničenim oblikom bolesti. Atipični ili ograničeni oblik bolesti pripada skupini sindroma sine u upalnim reumatskim bolestima, koji nisu česti, ali ih je potrebno razmotriti pri diferencijalnoj dijagnozi. Prema našim saznanjima, samo je nekoliko opisanih prikaza bolesnika sa sličnom prezentacijom bolesti.

KLJUČNE RIJEČI: Vaskulitis povezan s antineutrofilnim citoplazmatskim protutijelima - dijagnoza, patologija; Antineutrofilna citoplazmatska protutijela - analiza; Granulomatoza s poliangiitisom - dijagnoza, farmakoterapija, patologija; Purpura - etiologija; Glomerulonefritis - etiologija, patologija; Artritis - etiologija

\section{INTRODUCTION}

Antineutrophil cytoplasmic autoantibody (ANCA)-associated vasculitis is a small-vessel vasculitis characterized by necrotizing inflammation of small vessels and positive ANCAs. ANCA-associated vasculitis is subdivided into granulomatosis with polyangiitis (GPA, formerly known as Wegener's granulomatosis), microscopic vasculitis (MPA), eosinophilic granulomatosis with polyangiitis (EGPA or Churg-Strauss vasculitis), and ANCA-positive renal-limited vasculitis (RLV) as a special entity (1). ANCA-associated vasculitis is characterized by positive ANCA antibodies. These antibodies are directed against proteinase 3 (PR-3) or cANCA, and against myeloperoxidase (MPO) or pANCA antibodies. cANCA antibodies are characteristic for GPA, with high sensitivity (especially in active, systemic disease) (2) and specificity (3). Although the presence of cANCAs in GPA is well established, the immunopathology of the disease is still unclear, and individuals with no signs of active disease can have a high antibody titer (2). GPA is characterized by granulomatous inflammation that affects the upper and lower respiratory tract and blood vessel inflammation (vasculitis), which can damage organ systems. The areas most commonly affected by GPA include the sinuses, lungs, and kidneys, but any site can be affected (4).

The estimated annual incidence of GPA in Europe is about 2-12 per million and the prevalence of GPA is 24-157 per million (5).

Several diagnostic criteria are used to establish the diagnosis of GPA. The American College of Rheumatology (ACR) 1990 classification criteria for GPA include the following: 1) nasal or oral inflammation

\section{UVOD}

Vaskulitis povezan s antineutrofilnim citoplazmatskim protutijelima (engl. Anti-neutrophil Cytoplasmatic Antibody - ANCA) ili skraćeno ANCA vaskulitis (engl. ANCA-associated vasculitis - AAV) karakteriziraju nekrotizirajuća upala malih krvnih žila i pozitivan nalaz ANCA-e. Vaskulitisi povezani s ANCA-om dijele se na granulomatozu s poliangiitisom (GPA) koja je prije bila poznata pod nazivom Wegenerova granulomatoza, mikroskopski vaskulitis (MPA), eozinofilnu granulomatozu s poliangiitisom (EGPA ili Churg-Straussin vaskulitis) i ANCA-pozitivni vaskulitis ograničen na bubrege (RLV) kao poseban entitet (1). Značajka ANCA vaskulitisa jest pozitivan nalaz protutijela ANCA, koja mogu biti usmjerena na proteinazu 3 (PR-3) pa se nazivaju c-ANCA i na mijeloperoksida$\mathrm{zu}$ (MPO) te se zovu p-ANCA. Protutijela c-ANCA karakteristična su za GPA, $s$ visokim razinama osjetljivosti (osobito kod aktivne, sistemske bolesti) (2) i specifičnosti (3). Iako je prisutnost protijela cANCA kod GPA dobro utvrđena, imunopatologija bolesti još nije razjašnjena i osobe bez ikakvih znakova aktivne bolesti mogu imati visok titar tih protutijela (2). GPA je karakteriziran granulomatoznom upalom što zahvaća gornje i donje dišne putove te upalom krvnih žila (vaskulitisom) koji može uništiti organske sustave. Organi koje GPA najčešće zahvaća jesu sinusi, pluća i bubrezi, ali može zahvatiti bilo koji organ ili dio tijela (4).

Procjenjuje se da godišnja incidencija GPA u Europi iznosi 2 - 12 na milijun osoba, a prevalencija $24-157$ na milijun osoba (5).

Pri postavljanju dijagnoze GPA rabi se nekoliko dijagnostičkih kriterija. Klasifikacijski kriteriji Američkog društva za reumatologiju (ACR) iz 1990. godine za 
(painful or painless oral ulcers, or purulent or bloody nasal discharge); 2) abnormal chest radiograph showing nodules, fixed infiltrates, or cavities; 3 ) abnormal urinary sediment (microscopic hematuria with or without red cell casts); 4) granulomatous inflammation on biopsy of an artery or perivascular area (6). The presence of two or more of these four criteria yielded a sensitivity of $88 \%$ and a specificity of $92 \%$.

The European Medicines Agency (EMA) algorithm suggested that the surrogate markers might permit the diagnosis of GPA to be made in the absence of a biopsy (7). These surrogate markers include: 1) lower airways: radiograph evidence of fixed pulmonary infiltrates, nodules, or cavitations for more than one month, or bronchial stenosis; upper airways: bloody nasal discharge and crusting for more than one month or nasal ulceration; 2) chronic sinusitis, otitis media, or mastoiditis for more than three months; retro-orbital mass or inflammation; subglottic stenosis; saddle nose deformity/destructive sinonasal disease; 3) glomerulonephritis: hematuria associated with red cell casts or $>10$ dysmorphic red cells; or $2+$ hematuria or $2+$ proteinuria on the dipstick; and 4) positive ANCAs in patients with surrogate markers for GPA allow a diagnosis of GPA without a biopsy.

The clinical presentation of the disease in approximately $90 \%$ of the cases includes ear-nose-throat (ENT) symptoms like nasal crusting, sinus pain, chronic rhinosinusitis, nasal obstruction, or bloody nasal discharge. Symptoms related to pulmonary involvement are present in approximately two-thirds of the patients. Respiratory symptoms mostly include cough, hemoptysis, dyspnea, and pleuritic pain (8). Among patients with GPA, it is unusual for pulmonary symptoms to occur in the absence of upper respiratory tract symptoms or signs. Renal involvement is the third main manifestation of GPA and usually includes glomerulonephritis associated with few or no immune deposits in the glomeruli (pauci-immune glomerulonephritis) visible on immunofluorescence and electron microscopy (9). Neurological involvement is present in one-third of the patients. In $10-50 \%$ of the patients, skin lesions are present, with palpable purpura on the legs and feet as the most common manifestation. Constitutional symptoms, such as fever and weight loss, are present in $30-80 \%$ of the patients. Non-erosive polyarthritis affecting medium- and large-size joints is described in two-thirds of the patients. Other manifestations include eye involvement (mainly episcleritis) and, rarely, gastrointestinal and cardiac manifestations (10).

The treatment of GPA is comprised of the induction regimen (with high-dose glucocorticoids and immunosuppressant agents) followed by maintenance treatment (with less toxic agents if possible). For the induc-
GPA uključuju ovo: 1) upalu nosne ili usne šupljine (bolne ili bezbolne ulceracije u ustima ili gnojni ili krvavi iscjedak iz nosa); 2) abnormalni radiografski nalaz pluća koji pokazuje čvoriće, fiksne plućne infiltrate ili kavitacije; 3 ) abnormalni sediment urina (mikroskopska hematurija s eritrocitnim cilindrima ili bez njih); 4) patohistološki nalaz granulomatozne upale arterije ili perivaskularnog područja (6). Prisutnost dvaju ili više ovih kriterija ima osjetljivost od $88 \%$ i specifičnost od $92 \%$.

Europska agencija za lijekove (EMA) ponudila je algoritam prema kojem se dijagnoza GPA može postaviti na temelju zamjenskih biljega i bez biopsije (7). Ti zamjenski biljezi uključuju ovo: 1) donji dišni putovi: radiografski dokazani fiksni plućni infiltrati, čvorići ili kavitacije tijekom više od mjesec dana ili bronhalna stenoza; 2) gornji dišni putovi: krvavi iscjedak iz nosa i krustacije tijekom više od mjesec dana ili nosne ulceracije; kronični sinusitis, otitis media ili mastoiditis tijekom više od tri mjeseca; upala retroorbitalnog tkiva, subglotalna stenoza; deformitet nosa u obliku sedlastog nosa / destruktivna bolest nosa i sinusa; 3) glomerulonefritis: hematurija s eritrocitnim cilindrima ili $>10$ dismorfnih eritrocita; ili hematurija $2+$ ili proteinurija 2+ na urinskoj testnoj vrpci; 4) pozitivna protutijela ANCA u bolesnika sa zamjenskim biljezima za GPA dopuštaju dijagnozu GPA bez biopsije.

Klinička prezentacija bolesti u približno $90 \%$ bolesnika uključuje otorinolaringološke simptome poput stvaranja krasta u nosu, bol u sinusima, kronični rinosinusitis, opstrukciju nosa ili krvavi iscjedak iz nosa. Simptomi koji upućuju na zahvaćenost pluća prisutni su u približno dvije trećine bolesnika. Respiratorni simptomi uglavnom uključuju kašalj, hemoptizu, dispneju i pleuralnu bol (8). Kod bolesnika s GPA nije uobičajeno da se plućni simptomi pojavljuju bez simptoma i znakova zahvaćenosti gornjih dišnih putova. Bubrežni poremećaj treća je glavna manifestacija GPA, obično u obliku glomerulonefritisa povezanog s vrlo malo ili nimalo imunodepozita u glomerulima ( $p a u-$ ciimuni glomerulonefritis) vidljivih imunofluorescencijom ili elektronskom mikroskopijom (9). Neurološki znakovi prisutni su u trećine bolesnika. U $10-50 \%$ bolesnika prisutne su kožne lezije s palpabilnom purpurom na nogama i stopalima kao najčešćom manifestacijom. Konstitucijski simptomi poput vrućice i gubitka tjelesne težine prisutni su u $30-80 \%$ bolesnika. Neerozivni poliartritis srednje velikih i velikih zglobova nalazi se u dvije trećine bolesnika. Druge manifestacije uključuju zahvaćenost oka (uglavnom episkleritis) i, rijetko, gastrointestinalne i srčane manifestacije (10).

Liječenje GPA sastoji se od indukcijskog liječenja (visokim dozama glukokortikoida i imunosupresiva), a zatim terapije održavanja (prema mogućnosti manje toksičnim lijekovima). Pri indukcijskom liječenju bo- 
tion treatment in life-threatening or organ-threatening disease, cyclophosphamide and rituximab are recommended in rapidly progressive kidney failure, and diffuse alveolar hemorrhage, plasma exchange therapy is an option. In the case of limited disease, the first choice of treatment can be mycophenolate mofetil (MMF) or methotrexate (11).

\section{CASE REPORT}

A 46-year-old Caucasian female patient had initial symptoms of weight loss, and swelling and pain in both ankles 4 months prior to workup in our clinic. She had no relevant history of chronic illness and was not taking any therapy.

One month after the patient's symptoms had started, she was examined by a physiatrist due to the swelling and pain in her ankles and purpuric rash on her legs that resolved spontaneously. Reactive arthritis was suspected and she was recommended to take $4 \mathrm{mg}$ of methylprednisolone, which she took for a couple of weeks and then stopped since her symptoms persisted despite the therapy. Three months later, the patient was admitted to the Infectious Diseases Department in a General County Hospital due to persistent intermittent high fever (with maximum axillary temperature of $38.6^{\circ} \mathrm{C}$ ). Antibiotics were started empirically, but there was no resolution of the symptoms. Blood and urine cultures were negative, chest X-ray scan and abdominal ultrasound were unremarkable. Tumor markers were negative, and since no infectious cause was found, the patient was discharged from the hospital and referred to a rheumatologist. But due to the reappearance of the purpuric rash on her legs, she was examined at the University Hospital Center Emergency Department and was then admitted to the Department of Rheumatology, Clinical Immunology, and Allergology.

On admission, the patient's major complaint was high fever that had been present in the previous 3 months, weight loss (8 $\mathrm{kg}$ in that period), and arthralgia of the ankle joints. Physical examination revealed palpable purpura on the legs and swollen, painful ankles. Her family history was negative for autoimmune diseases. The patient had been taking ibuprofen 600 $\mathrm{mg}$ three times daily. Laboratory findings during her stay at the Infectious Diseases Department showed anemia with elevated ESR and CRP and hypergammaglobulinemia. The patient denied bloody discharge from her nose, wheezing, dyspnea, or cough. Physical examination revealed no saddle nose. Her chest and heart sounds were normal, there was no liver and spleen enlargement, and no peripheral lymphadenopathy was present. The laboratory findings showed elevated CRP $84.7 \mathrm{mg} / \mathrm{L}$ (ref. range <5), ESR $70 \mathrm{~mm} / 3.6$ KS (range: 4-24), anemia with hemoglobin $108 \mathrm{~g} / \mathrm{L}$ (range: 119-157), and ferritin 283.9 ug/L (range: 10- lesti koja ugrožava život ili organe ciklofosfamid i rituksimab preporučuju se kod brzoprogredirajućeg zatajenja bubrega, a kod difuznog alveolarnog krvarenja mogući je izbor terapijska izmjena plazme. Ako je bolest ograničena, prvi izbor liječenja mogu biti mikofenolatmofetil (MMF) ili metotreksat (11).

\section{PRIKAZ BOLESNICE}

Početni simptomi žene u dobi od 46 godina bili su gubitak tjelesne težine te oticanje i bol u oba gležnja 4 mjeseca prije obrade u našoj klinici. Dotad nije bolovala ni od kakve kronične bolesti i nije uzimala nikakvu terapiju.

Mjesec dana nakon početka simptoma bolesnicu je pregledao fizijatar zbog oticanja i bolnosti gležnjeva te purpurnog osipa na nogama koji se spontano povukao. Zbog sumnje na reaktivni artritis bolesnici je preporučeno da uzima $4 \mathrm{mg}$ metilprednizolona, što je i činila nekoliko tjedana, a zatim prestala jer su simptomi trajali unatoč terapiji. Tri mjeseca poslije bolesnica je primljena na Odjel za zarazne bolesti Opće županijske bolnice zbog perzistentne intermitentne vrućice (najviša aksilarna temperatura od $38,6^{\circ} \mathrm{C}$ ). Započeta je empirijska terapija antibioticima, ali nije dovela do povlačenja simptoma. Kulture krvi i urina bile su negativne, rendgenogram srca i pluća te ultrazvuk abdomena bili su bez obilježja. Tumorski biljezi bili su negativni, a budući da nije nađen infektivni uzročnik, bolesnica je otpuštena iz bolnice te upućena reumatologu. Međutim, zbog ponovne pojave purpurnog osipa po nogama pregledana je na Odjelu za hitnu pomoć Sveučilišne bolnice te primljena na Odjel za reumatologiju, kliničku imunologiju i alergologiju.

Nakon prijma bolesnica se najviše žalila na visoku tjelesnu temperaturu prisutnu tijekom prethodna 3 mjeseca, gubitak tjelesne težine ( $8 \mathrm{~kg}$ u tom razdoblju) i artralgiju u području gležnjeva. Na fizikalnom pregledu uočeni su palpabilna purpura na nogama te otečeni, bolni gležnjevi. U obiteljskoj anamnezi nije bilo autoimunosnih bolesti. Bolesnica je uzimala ibuprofen $u$ dozi od $600 \mathrm{mg}$ tri puta na dan. Laboratorijski nalazi tijekom njezina boravka na Odjelu za zarazne bolesti pokazali su anemiju s povišenom sedimentacijom eritrocita i vrijednošću CRP-a te hipergamaglobulinemiju. Negirala je krvavi iscjedak iz nosa, piskanje pri disanju, dispneju ili kašalj. Na fizikalnom pregledu nije nađen sedlasti nos, šum disanja i srčani tonovi bili su normalni, nije bilo povećanja jetre i slezene ni periferne limfadenopatije. Laboratorijski nalazi pokazali su povišenu vrijednost CRP-a od $84,7 \mathrm{mg} / \mathrm{L}$ (referentni raspon: $<5$ ), sedimentaciju eritrocita od $70 \mathrm{~mm} / 3,6 \mathrm{ks}$ (raspon: 4 - 24), anemiju uz vrijednosti hemoglobina od $108 \mathrm{~g} / \mathrm{L}$ (raspon: 119 - 157) i feritina od $283,9 \mu \mathrm{g} / \mathrm{L}$ (raspon: $10-120$ ). Klirens kreatinina bio je $1,41 \mathrm{~mL} / \mathrm{s}$ $1,73 \mathrm{~m}^{2}$ (raspon: $1,60-2,94$ ), uz 24-satnu proteinuriju 
120). Creatinine clearance was $1.41 \mathrm{~mL} / \mathrm{s} 1.73 \mathrm{~m}^{2}$ (range: 1.60-2.94), with 24-hour proteinuria of $767 \mathrm{mg} / \mathrm{dU}$ $(<150)$; BUN and creatinine levels were normal. Autoantibodies were tested and showed positive ANA 1:320 on cytoplasmic fluorescence, with positive actin antibodies, ENA screen, and cardiolipin antibodies. RF and anti-CCP were negative with normal $\mathrm{C} 3$ and $\mathrm{C} 4$. pANCA and anti-GBM were negative. cANCAs were highly positive: 771 (positive $>25$, tested on xMAP Luminex assay 200).

The patient was examined by an ear-nose-throat specialist. Rhinoscopy, laryngoscopy, and otoscopy were performed and no signs of upper airway involvement were found. Chest X-ray was unremarkable, as well as US of the abdomen, ECG, heart ultrasound, and ophthalmological exam. Repeated urine erythrocyte morphology revealed $13 \%, 21 \%$ and $18 \%$ of dysmorphic erythrocytes in samples taken on 3 consecutive days. Cytological urine sediment was negative for malignant cells and bacteria. Blood and urine cultures were negative, so prednisolone $1 \mathrm{mg} / \mathrm{kg}$ was initiated. Kidney biopsy was performed and a diagnosis of rapidly progressive pauci-immune glomerulonephritis was confirmed.

Additionally, testing showed negative $\mathrm{HBV}, \mathrm{HCV}$ antibodies, and QuantiFeron TB Gold test. EBV and CMV antibodies revealed past contact. MSCT of the paranasal cavities was unremarkable. Lung function tests (spirometry and DLCo) were normal. Immunofixation electrophoresis revealed two oligoclonal bands (IgG type kappa). Bone marrow aspiration was performed and was unremarkable.

The diagnosis of cANCA-associated vasculitis was made and treatment was started with an induction regimen that included glucocorticoids in tapering dosage and cyclophosphamide $(15 \mathrm{mg} / \mathrm{kg}$ every two weeks for the first three cycles, followed by application every three weeks for 6 months). After the initial treatment, the symptoms rapidly improved, and the arthritis, fever, and purpura completely resolved. The patient's appetite improved and she gained weight. Her laboratory results were: CRP $10 \mathrm{mg} / \mathrm{L}$ (ref. range< 5), ESR 25 $\mathrm{mm} / 3.6 \mathrm{KS}$ (range: 4-24), hemoglobin $130 \mathrm{~g} / \mathrm{l}$ (range: 119-157), with no erythrocyturia or proteinuria. cANCAs remained positive (440, positive $>25)$. After the remission was achieved, maintenance treatment with azathioprine was continued. The patient had no signs and symptoms of pulmonary involvement during the treatment or at follow-up. Because of the unusual presentation of the disease, the ENT examination was repeated and no signs of upper airway involvement were found. Initially, no MSCT of chest organs had been done due to technical reasons, but during the follow-up, a HRCT of lungs was ultimately performed and showed no signs of interstitial lung involvement, no hilar or od $767 \mathrm{mg} / \mathrm{dU}(<150)$; BUN i kreatinin imali su normalne vrijednosti. Testovima na autoantitijela nađeni su pozitivan ANA 1:320 citoplazmatskom fluorescencijom te pozitivna protutijela na aktin, ENA probir i kardiolipinska protutijela. RF i anti-CCP bili su negativni, uz normalne C3 i C4. p-ANCA i anti-GBM bili su negativni. Protutijela c-ANCA bila su visokopozitivna: 771 (pozitivan nalaz: $>25$, ispitano testom xMAP Luminex 200).

$\mathrm{Na}$ otorinolaringološkom pregledu bolesnici su učinjene rinoskopija, laringoskopija i otoskopija, no nisu nađeni znakovi zahvaćenosti gornjih dišnih putova. Rendgenogram srca i pluća bio je bez osobitosti, kao i ultrazvuk abdomena, EKG, ultrazvuk srca te oftalmološki pregled. Ponovljena analiza morfologije eritrocita u urinu pokazala je 13, 21 i 18\% dismorfnih eritrocita u uzorcima uzetima 3 dana zaredom. Citološka analiza sedimenta urina bila je negativna na zloćudne stanice i bakterije. Kulture krvi i urina bile su negativne pa se započelo s primjenom prednizolona u dozi od $1 \mathrm{mg} / \mathrm{kg}$. Provedena je biopsija bubrega kojom je potvrđena dijagnoza brzoprogresivnoga pauciimunoga glomerulonefritisa.

Usto, rezultati testova protutijela na $\mathrm{HBV}$ i $\mathrm{HCV}$, kao i testa QuantiFeron-TB Gold bili su negativni. Protutijela na EBV i CMV upozorila su na prethodni kontakt s tim virusima. MSCT paranazalnih sinusa bio je uredan. Testovi plućne funkcije (spirometrija i DLCo) bili su normalni. Imunofiksacijska elektroforeza pokazala je dvije oligoklonske vrpce (IgG tipa kapa). Provedena je aspiracija koštane srži i nalaz je bio uredan.

Postavljena je dijagnoza c-ANCA vaskulitisa i započeto liječenje indukcijskom terapijom koja se sastojala od glukokortikoida u postupno sve nižoj dozi i ciklofosfamida ( $15 \mathrm{mg} / \mathrm{kg}$ svaka dva tjedna za vrijeme prva tri ciklusa, a zatim primjena svaka tri tjedna tijekom 6 mjeseci). Nakon toga početnog liječenja simptomi su se brzo poboljšali, a artritis, vrućica i purpura potpuno su se povukli. Bolesnici se poboljšao apetit $\mathrm{i}$ dobila je na tjelesnoj težini. Laboratorijski rezultati bili su ovi: CRP $10 \mathrm{mg} / \mathrm{L}$ (referentni raspon: <5), sedimentacija eritrocita $25 \mathrm{~mm} / 3,6 \mathrm{ks}$ (raspon: $4-24$ ), hemoglobin 130 g/L (raspon: 119 - 157), bez eritrociturije ili proteinurije. Protutijela c-ANCA ostala su pozitivna (440; pozitivan nalaz: > 25). Budući da je postignuta remisija, nastavljeno je s njezinim održavanjem primjenom azatioprina. Tijekom liječenja i kasnijih kontrolnih pregleda bolesnica nije imala znakova i simptoma zahvaćenosti pluća. Zbog neobične prezentacije bolesti ponovljen je otorinolaringološki pregled, no nisu nađeni znakovi bolesti u gornjim dišnim putovima. Početno nije obavljen MSCT torakalnih organa zbog tehničkih razloga, ali tijekom kontrolnih pregleda naposljetku je učinjen HRCT pluća koji nije pokazao nikakvih znakova intersticijskih plućnih promjena 
mediastinal lymphadenopathy, no effusions or consolidates, and no infiltrates on the lung parenchyma.

\section{DISCUSSION}

Our patient had an unusual presentation of cANCA vasculitis, which was successfully treated. cANCA antibodies are characteristic for GPA, although their role in the immunopathology of the disease is still unclear because a high titer is possible although remission has been achieved (12-14). cANCA antibodies are highly specific for GPA, with high sensitivity, especially in the systemic form of the disease $(2,3)$. This is why EMA suggests that the diagnosis of GPA can be based on cANCA positivity and established clinical features of the disease (7). The most common presentation of GPA includes airway involvement (10), and there are few case reports of patients with cANCA vasculitis without known airway involvement (15-18).

Such cases are described as a partial or atypical form of Wegener's disease. In 1985, Hensen et al. reported a case of a 30-year-old patient with an angiocentric granulomatous change on her lip and rapidly progressive crescentic glomerulonephritis (15). The patient also had skin changes on her legs that were proven to be discoid lupus by a biopsy. The diagnosis of atypical Wegener's disease was made. Kawikaza et al. reported a 68-year-old woman with arthralgia, ophthalmologic manifestations, chronic renal failure due to RPGN, and highly positive cANCA-positive antibodies, who had no airway involvement (16).

Our patient had biopsy-proven crescentic, pauciimmune glomerulonephritis, with highly positive cANCA antibodies. Although the term renal limited vasculitis is known, in most cases these are forms of pANCA-positive renal-limited vasculitis (17). In a retrospective, epidemiologic survey, Fujimoto tried to establish the incidence of ANCA-positive RLV (18). Findings showed that among the RLV patients there were no cANCA- positive ones, and $91 \%$ of them were pANCA-positive.

Our patient, apart from the renal involvement, had arthritis and typical skin changes with prominent constitutional symptoms (fever, weight loss). As she had no airway involvement, she did not meet the ACR criteria (7) necessary for a diagnosis of GPA. However, due to cANCA positivity, which is a hallmark of GPA, especially at high titers as found in our case, accompanied by pauci-immune glomerulonephritis as well as joint and skin involvement, the diagnosis of atypical GPA was clear.

These atypical forms of the disease are very rare in clinical practice and there are only a few literature reports. That is why Rovensky introduced the term sine syndromes, which represents atypical forms of inflammatory rheumatic diseases, the courses of which are often severe (19). Sine syndromes do not meet the ni hilarnu ili medijastinalnu limfadenopatiju ni izljev ili konsolidaciju ili infiltrate plućnog parenhima.

\section{RASPRAVA}

Naša je bolesnica imala neobičnu prezentaciju c-ANCA vaskulitisa koji je uspješno liječen. Protutijela c-ANCA karakteristična su za GPA, iako njihova uloga u imunopatologiji ove bolesti još nije razjašnjena, jer mogu biti prisutna i u visokom titru unatoč postignutoj remisiji $(12-14)$. Ta su protutijela visokospecifična za GPA te imaju visoku osjetljivost, osobito pri sistemskim oblicima bolesti $(2,3)$. Zbog toga je EMA predložila da se dijagnoza GPA temelji na pozitivnom nalazu protutijela c-ANCA i prisutnim kliničkim znakovima bolesti (7). Najčešći klinički oblik GPA zahvaća dišne putove (10), no opisano je i nekoliko bolesnika s c-ANCA vaskulitisom bez poznate zahvaćenosti dišnih putova $(15-18)$.

Takvi su slučajevi opisani kao djelomični ili atipični oblik Wegenerove granulomatoze. Hansen i suradnici opisali su 1985. godine 30-godišnju bolesnicu s angiocentričnom granulomatoznom promjenom na usni i brzoprogresivnim glomerulonefritisom s polumjesecima (15). Bolesnica je imala kožne promjene i na nogama za koje se na biopsiji pokazalo da su diskoidni lupus. Postavljena je dijagnoza Wegenerove bolesti. Kakizawa i suradnici opisali su 68 -godišnju ženu s artralgijom, oftalmološkim manifestacijama, kroničnim zatajenjem bubrega zbog brzoprogresivnoga glomerulonefritisa te $s$ visokopozitivnim protutijelima c-ANCA u koje su dišni putovi bili pošteđeni (16) .

Naša je bolesnica imala biopsijom potvrđen pauciimuni glomerulonefritis s polumjesecima i visokopozitivna protutijela c-ANCA. Iako je poznat izraz vaskulitis ograničen na bubrege, najčešće je riječ o oblicima pANCA-pozitivnog vaskulitisa ograničenoga na bubrege (17). U retrospektivnom epidemiološkom ispitivanju Fujimoto pokušao je ustanoviti incidenciju ANCA-pozitivnog vaskulitisa ograničenoga na bubrege (18). Rezultati su pokazali da među tim bolesnicima nije bilo onih s pozitivnim protutijelima c-ANCA i da je njih $91 \%$ bilo p-ANCA-pozitivno.

U naše su bolesnice, osim zahvaćenosti bubrega, bili prisutni artritis i tipične kožne promjene s izrazitim konstitucijskim simptomima (vrućica, gubitak tjelesne težine). Budući da dišni putovi nisu bili zahvaćeni, prema ACR-u (7), nije zadovoljavala kriterije potrebne za dijagnozu GPA. Međutim, zbog pozitivnih protutijela c-ANCA koja su tipična za GPA, osobito ako su prisutna $\mathrm{u}$ visokom titru kao kod naše bolesnice, $\mathrm{u}$ kombinaciji s pauciimunim glomerulonefritisom te zahvaćenošću kože i zglobova, bilo je jasno da je riječ o atipičnom GPA.

Ti atipični oblici bolesti vrlo su rijetki u kliničkoj praksi i u literaturi je opisano svega nekoliko slučajeva. Zato je Rovenský uveo izraz sindromi sine što obuhva- 
standard criteria used to assist in the classification of patients with rheumatological disorders.

\section{CONCLUSION}

In this paper we presented a patient with an atypical presentation of GPA, with renal, joint, and skin involvement. At the time of the initial symptoms and throughout the clinical course of the disease, the patient had no signs and symptoms of airway involvement. This was also confirmed by diagnostic procedures. These atypical forms of the disease are important for consideration, due to the timely establishment of a proper diagnosis and initiation of optimal treatment. This is why in rheumatology, sine syndromes are a reminder to clinicians that unusual presentations of inflammatory rheumatic diseases are always possible and should be considered.

Conflict of interest statement: Authors declare no conflict of interest.

\section{REFERENCES / LITERATURA}

1. Jennette JC, Falk RJ, Andrassy K i sur. Nomenclature of systemic vasculitides. Proposal of an international consensus conference. Arthritis Rheum. 1994;37(2):187-92.

2. Finkielman JD, Lee AS, Hummel AM i sur.; WGET Research Group. ANCA are detectable in nearly all patients with active severe Wegener's granulomatosis. Am J Med. 2007;120(7):643. e9-14.

3. Stone JH, Talor M, Stebbing J i sur. Test characteristics of immunofluorescence and ELISA tests in 856 consecutive patients with possible ANCA-associated conditions. Arthritis Care Res. 2000;13(6):424-34.

4. Bacon PA. The spectrum of Wegener's granulomatosis and disease relapse. N Engl J Med. 2005;352(4):330-2.

5. Mohammad AJ, Jacobsson LT, Westman KW i sur. Incidence and survival rates in Wegener's granulomatosis, microscopic polyangiitis, Churg-Strauss syndrome and polyarteritis nodosa. Rheumatology (Oxford). 2009;48(12):1560-5.

6. Leavitt RY, Fauci AS, Bloch DA, Michel BA, Hunder GG, Arend WP i sur. The American College of Rheumatology 1990 criteria for the classification of Wegener's granulomatosis. Arthritis Rheum. 1990;33(8):1101-7.

7. Abdulkader R, Lane SE, Scott DG, Watts RA. Classification of vasculitis: EMA classification using CHCC 2012 definitions. Ann Rheum Dis. 2013;72(11):1888.

8. Jennette JC, Falk RJ. Small-vessel vasculitis. N Engl J Med 1997;337(21:1512-23.

9. Falk RJ, Hogan S, Carey TS, Jennette JC. Clinical course of antineutrophil cytoplasmic autoantibody-associated glomerulonephritis and systemic vasculitis. The Glomerular Disease Collaborative Network. Ann Intern Med. 1990;113(9):656-63.

10. Lynch JP, White E, Tazelaar H, Langford CA. Wegener's granulomatosis: evolving concepts in treatment. Semin Respir Crit Care Med. 2004;25(5):491-521. ća atipične oblike upalnih reumatskih bolesti koje često imaju težak tijek (19). Sindromi sine ne ispunjavaju standardna mjerila koja pomažu u klasifikaciji bolesnika s reumatološkim bolestima.

\section{ZAKLJUČAK}

$\mathrm{U}$ ovom smo radu prikazali bolesnicu s atipičnom prezentacijom GPA, kojoj su bili zahvaćeni bubrezi, koža i zglobovi. U vrijeme prvih simptoma te tijekom cijelog tijeka bolesti bolesnica uopće nije imala znakove zahvaćenosti dišnih putova, što je potvrđeno i dijagnostičkim postupcima. Važno je imati na umu ove atipične oblike bolesti radi pravodobnog postavljanja točne dijagnoze i započinjanja optimalnog liječenja. Stoga su sindromi sine u reumatologiji podsjetnik kliničarima da su neobične prezentacije upalnih reumatskih bolesti uvijek moguće i potrebno ih je uzeti u obzir.

IzJaVA o Sukobu interesa: Autori izjavljuju da nisu u sukobu interesa.

11. Yates M, Watts RA, Bajema IM, Cid MC, Crestani B, Hauser T i sur. EULAR/ERA-EDTA recommendations for the management of ANCA-associated vasculitis. Ann Rheum Dis. 2016; 75(9):1583-94.

12. Kallenberg CG. Pathogenesis of ANCA-associated vasculitides. Ann Rheum Dis. 2011;70(Suppl. 1):159-63.

13. Tervaert JW, van der Woude FJ, Fauci AS, Ambrus JL, Velosa J, Keane WF i sur. Association between active Wegener's granulomatosis and anticytoplasmic antibodies. Arch Intern Med. 1989;149(11):2461-5.

14. Boomsma MM, Stegeman CA, van der Leij MJ, Oost W, Hermans J, Kallenberg CG i sur. Prediction of relapses in Wegener's granulomatosis by measurement of antineutrophil cytoplasmic antibody levels: a prospective study. Arthritis Rheum. 2000;43 (9):2025-33.

15. Hansen LS, Silverman S Jr, Pons VG, Hales M, Greenspan JS, Sagebiel RW i sur. Limited Wegener's granulomatosis: report of a case with oral, renal, and skin involvement. Oral Surg Oral Med Oral Pathol. 1985;60(5):524-31.

16. Kakizawa T, Ichikawa K, Yamauchi K i sur. Atypical Wegener's granulomatosis with positive cytoplasmic antineutrophil cytoplasmic antibodies, ophthalmologic manifestations, and slowly progressive renal failure without respiratory tract involvement. Intern Med. 1999;38(8):679-82.

17. Oliet A, Praga M, Vidaur F, Elósegui A, Usera G, Bello I. Periglomerular granulomatosis. A limited form of Wegener's granulomatosis with exclusive renal involvement? Arch Intern Med. 1988;148(6):1377-9.

18. Fujimoto S, Uezono S, Hisanaga S i sur. Incidence of ANCAassociated primary renal vasculitis in the Miyazaki Prefecture: the first population-based, retrospective, epidemiologic survey in Japan. Clin J Am Soc Nephrol. 2006;1(5):1016-22.

19. Rovenský J. Atypical Forms of Granulomatosis with Polyangiitis (Wegener's). U: Rovenský J, Herold M, Vašáková M (ur.). Sine Syndromes in Rheumatology. Beč: Springer-Verlag; 2013., str. 45-9. 